Copyright ( $) 2020$ University of Bucharest Printed in Romania. All rights reserved

ISSN print: $1224-5984$

ISSN online: $2248-3942$

Received for publication, June, 17, 2020

Accepted, July, 27, 2020

Original paper

\title{
Effects of rape seeds pelleting with bioactive products based on collagen and keratin extract on germination and plantlets development
}

\author{
MARIUS BECHERIȚU*1, ROXANA HOROIAȘ ${ }^{1}$, CRISTIAN FLORINEL \\ CIOINEAG ${ }^{1}$, PAUL BOROVINĂ ${ }^{1}$
}

${ }^{1}$ Probstdorfer Saatzucht Romania SRL, 20 Siriului Street, 014354, District 1, Bucharest, Romania

\begin{abstract}
The paper aims to present the stage in which the application of new biostimulatory products is done by pelleting rape seed before the sowing time, and not just by filmcoating it. The tested products are made of collagen and keratin hydrolysate, by-products remaining after processing animal skins. New laboratory tests have been required after the first field trials (2018-2019), in order to find a more viable option for applying the products. Most of the applied protective film is going to be lost in case of an abundant rain, the effects being much diminished. By applying clay as a protective coating, it is possible to keep these substances near the seed, which will manage to benefit from this nutritional intake for a longer period of time. Experiments were three-factorial, including three bioactive products (F1, F2, F3), three amounts of fungicides (1.5, 2 and 31 Tiuram $480 \mathrm{~g} / \mathrm{l}$ ), three clay layer variants (simple, in relation to $0.5: 1$ and $1: 1$, but also one with turmeric). New treatments' effects on germination proved to be very significant, leading to increases of $10-15 \%$ in the number of sprouted plants. The appearance and vigour of rape plantlets have been other physiological indicators that helped us to elaborate the second-year plot trials (2019-2020).
\end{abstract}

Keywords Rape seeds, pelleting, bioactive products, germination, plantlets.

To cite this article: BECHERIȚU M, HOROIAȘ R, CIOINEAG CF, BOROVINĂ P. Effects of rape seeds pelleting with bioactive products based on collagen and keratin extract on germination and plantlets development. Rom Biotechnol Lett. 2020; 25(5): 1953-1960. DOI: $10.25083 / \mathrm{rbl} / 25.5 / 1953.1960$

$\Omega$ *Corresponding author: MARIUS BECHERITU, Probstdorfer Saatzucht Romania SRL, 20 Siriului Street, 014354, District 1, Bucharest, Romania 


\section{Introduction}

For agricultural practice, seed has been and continues to be an increasingly valuable and indispensable basic input (J.C. DELOUCHE \& H.C. POTTS [1]; FAO [2]; K.K. SHARMA \& al [3]) as the demand for food increases in direct proportion to the population of the planet (S.G. ELIAS [4]). Good quality and correctly stored and treated seed will ensure a healthy and viable crop throughout the entire vegetation cycle, leading to rapid germination and homogeneous emergence (R. ZECCHINELLI [5]; Y. GUAN \& al [6]; W.E. FINCH-SAVAGE \& G.W. BASSEL [7]). Research in the field is required (C.J.M. ALMEKINDERS \& al [8]), improvement in post-harvest seed processing technology being necessary.

One way of processing seed is by pelleting it (A.A. POWELL \& S. MATTHEWS [9]), a method used mainly in the pharmaceutical and food fields (S.M. IVESON \& al [10]). In a nutshell, pelleting is a treatment applied to seeds through a granulation process (M.A. BEHJANI \& al [11]) that leads to changes in their physical and physiological properties, improving their shape and strength (L. SUN \& al [12]). The process is mainly used in horticulture (J.C. BISHOP [13]), where the seeds are very small and difficult to use (R. KUMAR \& R. MUTHUKRISHNAN [14]), but proving its usefulness for precision sowing, it began to be used for other crops too, including rape. Pelleting has become a support for farmers (H.J. HILL [15], protecting the seed from biotic and abiotic stresses (B. JYOTI \& S. BHANDARI [16]), depending on the properties of the applied treatment, but also on those of the used filler material.

More and more specialists recommend the use of protein products of natural origin, enriched with micro- and macronutrients, with effects in stimulating germination, in nutrition and in plant protection (J.A. LEWIS \& al [17]; V.V. GEETHA \& P. BALAMURUGAN [18]; M. FAROOQ \& al [19]; D. MIHALACHE \& al [20]; M.D. NICULESCU \& al [21]) and of an optimal granulation layer (M. DOMARADZKI \& al [22]), with nutritional properties for plants and soil, but also with the ability to absorb the necessary amount of water for germination and emergence (P. GRELLIER \& al [23]; J. MEI \& al [24]).

The qualitative and quantitative characteristics of rape crop imply the continuous improvement of agricultural engineering methods, which include biological progress in several directions (A. STEPIEN \& al [25]). Being a winter crop, resistance to very low temperatures is vital, as it is the optimal development before winter starts. In this context, all the elements must be taken into account - pedoclimatic and agrotechnical conditions, seed treatment, sowing date (J. ZENG \& al [26]; I. BALALIC \& al [27]), plantlets vigour (S. CHANNAOUI \& al [28]) etc. Through this paper we aimed to present the results of germination and development of plantlets obtained by pelleted rape seed with bioactive products, with stimulating effect, based on collagen hydrolysates and keratin of animal origin (M. GIDEA \& al [29]; K. LAWINSKA \& al [30]).

\section{Materials and Methods}

\section{Preparing seeds for treatment}

Rape seed pelleting is preceded by their conditioning. Seed cleaning and sorting are operations that consist of removing impurities and separating the seeds into categories depending on size and weight.

For these operations the fanner, the sampler and the selector are used. Rape seeds are very small (MTG $=3-4 \mathrm{~g}$ ) and therefore the spaces between the seeds are also small and the air penetrates very hard between them.

\section{Preparation of mixtures for treatment}

According to our previous experiences for bioactive products based on collagen and keratin, a quantity of 101 solution / $\mathrm{t}$ seed (out of which 21 of tested products), in various mixtures, has been used for film-coating. Now, the same quantity is going to be used for pelleting process.

Pelleting has been done in two successive stages. Basically, the first stage of testing led us to the second one, in order to confirm the results obtained and to facilitate the choice of the best treatment variants to use them after in the research field, whose purpose is to validate or invalidate the results obtained in the laboratory.

Trifactorial experiments have been performed with rape seeds, Harry variety (property of Probstdorfer Saatzucht $\mathrm{GmbH}$ ).

Raw materials used in the first test cycle (Test I):

$\rightarrow$ F1, F2, F3 new bioactive products - ratio of 2:8 1/t seeds (Figure 1 );

$\rightarrow$ F1/F2/F3 + Tiuram $480 \mathrm{~g} /$ l (fungicide) - ratio of 2:3:5 1/t seed (out of which 21 collagen extract, 31 Tiuram $480 \mathrm{~g} / \mathrm{l}, 5 \mathrm{l}$ water);

$\rightarrow$ filler material, clay powder, in $0.5: 1$ ratio $(0.5 \mathrm{~kg}$ clay to $1 \mathrm{~kg}$ rape seeds) and clay + turmeric versions (additional layer of $0.1: 1 \mathrm{~kg}$ of seeds, applied at the end, as repellent product).

Following the results obtained in the first testing phase, new treatments have been formulated, for which the same parameters have been calculated.

Raw materials used in the second test cycle (Test II):

$\rightarrow$ F1, F2, F3 new bioactive products - ratio of 2:8 1/t seeds;

$\rightarrow$ F1/F2/F3 + Tiuram $480 \mathrm{~g} / 1$ (fungicide) - ratio of 4:6 and 3.5:6.5 1/t seed (out of which 21 bioactive product, sequentially combined with 21 , then with 1.51 Tiuram $480 \mathrm{~g} / \mathrm{l}$ );

$\rightarrow$ filler material, clay powder - two variants with different quantities have been tested $-0.5: 1$ and $1: 1$ ratio (meaning $0.5 \mathrm{~kg}$ and $1 \mathrm{~kg}$ clay for $1 \mathrm{~kg}$ rape seeds).

The aim of pelleting process has been the covering of rape seeds with a layer of bioactive product, with biostimulatory effect, as well as creating a protective coating as homogeneous as possible, both in order to increase the germination capacity of the seeds and pushing a rapid development of the plantlets, to withstands the biotic and abiotic factors from the field. 


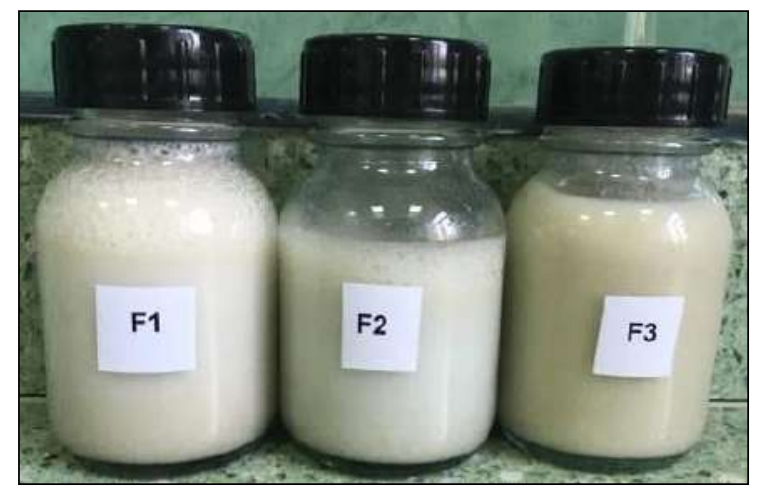

Figure 1. Bioactive products to be used in rape seeds pelleting testing process.

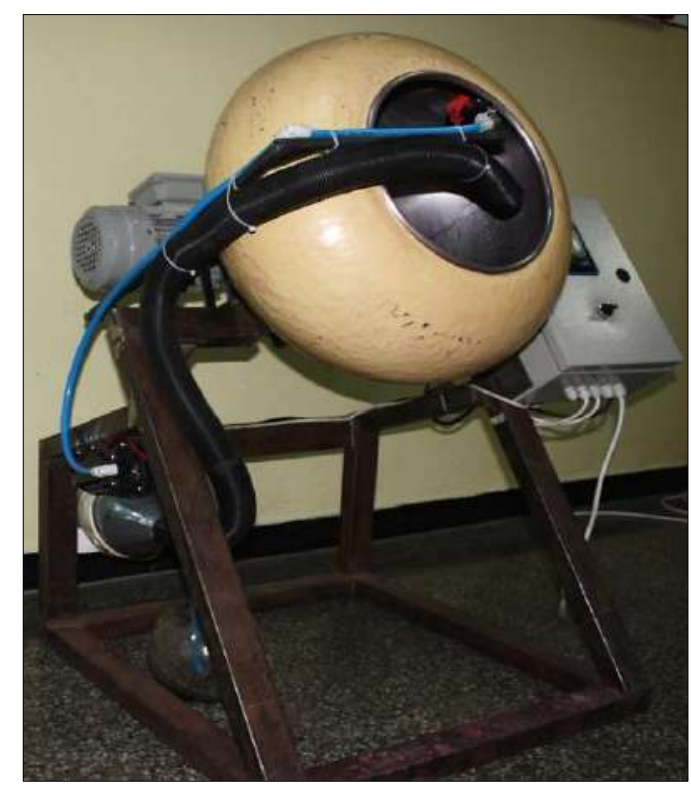

Figure 2. Pilot installation for seed treating and/or pelleting.

\section{Pelleting realization}

The equipment used for pelleting consists in a mixing tank that can rotate around its axis (Figure 2). The speed of the mixing tank is variable, with values between 20 and 150 rotations / minute, depending on the type of seeds.

Rape seeds prepared to be pelleted are put in the mixing tank. It starts the rotation of the mixing tank at a speed of 30 rotations/minute. The spraying system it turned on and half of the treatment mixture is added, in order to cover the seeds very well and to provide a binder for the granulating agent (clay powder or clay with turmeric). It's gradually added the clay and sprayed the rest of the treatment mixture, continuing to rotate the mixing tank. If the seeds remain grouped in one place, the speed of the mixing tank is increased. If the seeds adhere to the wall of the mixing tank and no continuous homogenization is achieved, the speed is reduced.

After incorporating the entire amount of filler material, the ventilation system at atmospheric temperature is started. If necessary, the temperature of the air used to dry the seeds can be raised to a maximum of $32^{\circ} \mathrm{C}$.

\section{Laboratory tests}

Samples of 1000 grains from each of the tested variants (Treatments 1-19), plus two control versions, have been taken and placed in the Binder germination chamber (Figure 3), where they were left for 8 days at a temperature of $20^{\circ} \mathrm{C}$.

Petri dishes with a capacity of 100 grains have been used to test the germination. As a result, 10 vessels were made for each treatment - a total of 110 vessels in the first phase of testing, 100 vessels in the second one.

\section{Results and Discussions}

Samples of $200 \mathrm{~g}$ of rape seeds have been pelleted, according to the methodology presented above, resulting the seeds from Figure 4, ready to be sown.

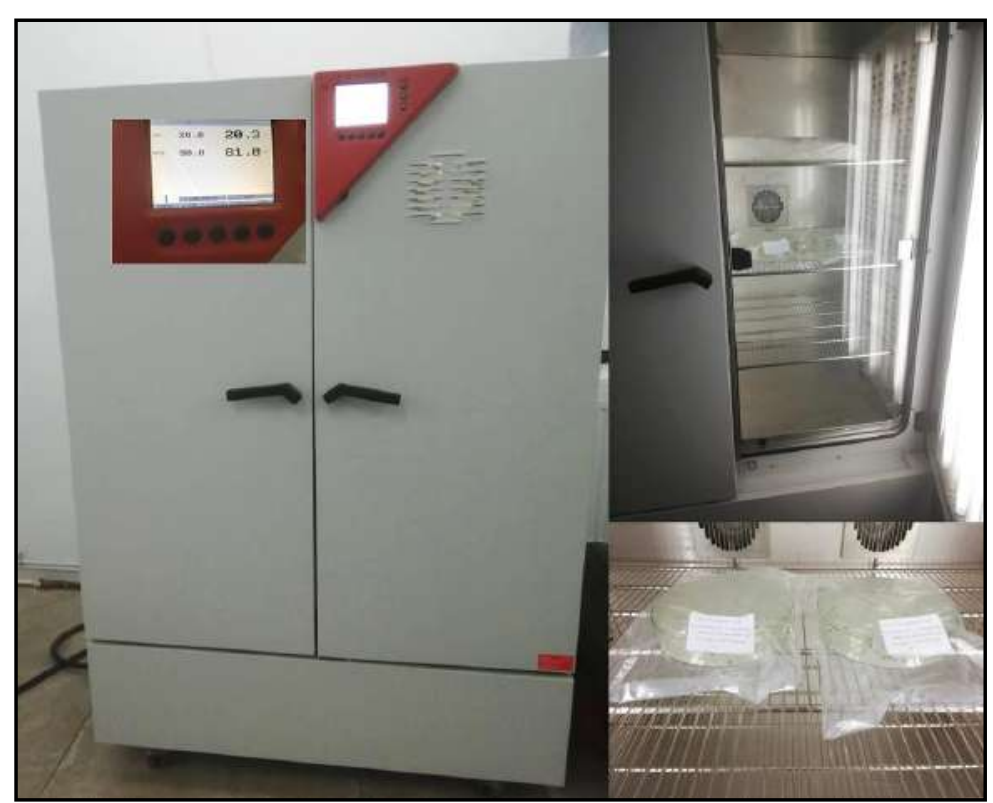

Figure 3. Binder germination room, where the pelleted seeds have been tested. 

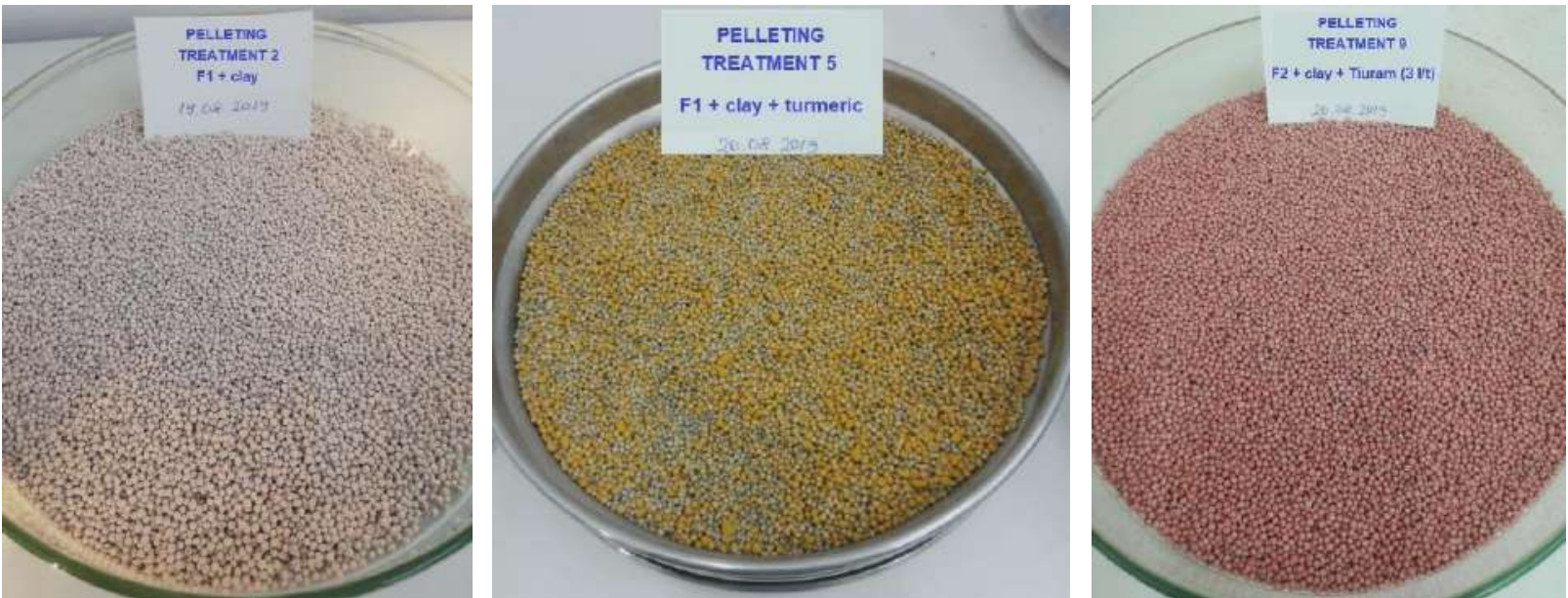

Figure 4. Some of the rape seeds obtained by pelleting process.

For each treatment applied, the evolution of the MTG (g) parameter has been followed, an important indicator in the evaluation of the granulation efficiency, in order to evaluate which of the mixtures are a better adhesive material for clay powder. As specific features, the variants with turmeric (Treatments 5-7) have been compromised, because the pelleting mixture, consisting of clay and turmeric $(0.5: 0.1: 1)$, didn't adhere to rape seeds, most likely because of the grinding incompatibility between the two components, resulting in glomerular formations in which no seeds were found - this aspect also explains the lower germination. As a result, germination was low and it was decided to give up on this ingredient.

The results obtained from the MTG measurement and from the germination reading are shown in Table 1 (Test I) and Table 2 (Test II).

Table 1. Results obtained after pelleting rape seeds - Test I

\begin{tabular}{|c|c|c|c|c|c|}
\hline \multirow{2}{*}{ Crt. } & \multirow{2}{*}{$\begin{array}{l}\text { Treatment } \\
\text { number }\end{array}$} & \multirow{2}{*}{ Treatment products } & \multicolumn{3}{|c|}{ Obtained results } \\
\hline & & & MTG (g) & $\begin{array}{c}\text { Germination } \\
(\%)\end{array}$ & Semnification \\
\hline 1. & Treatment 01 & Control - untreated & 3.32 & 78 & - \\
\hline 2. & Treatment 1 & Water + clay $(0.5: 1)$ & 4.79 & 81 & $* *$ \\
\hline 3. & Treatment 2 & $\mathrm{~F} 1+$ clay $(0.5: 1)$ & 5.12 & 95 & $* * *$ \\
\hline 4. & Treatment 3 & $\mathrm{~F} 2+\operatorname{clay}(0.5: 1)$ & 5.08 & 93 & $* * *$ \\
\hline 5. & Treatment 4 & F3 + clay $(0.5: 1)$ & 5.11 & 92 & $* * *$ \\
\hline 6. & Treatment 5 & $\begin{array}{c}\text { F1 + clay }(0.5: 1)+ \\
\text { turmeric }(0.1: 1)\end{array}$ & 4.49 & 82 & $*$ \\
\hline 7. & Treatment 6 & $\begin{array}{c}\text { F2 + clay }(0.5: 1)+ \\
\text { turmeric }(0.1: 1)\end{array}$ & 4.38 & 83 & $*$ \\
\hline 8. & Treatment 7 & $\begin{array}{c}\text { F3 + clay }(0.5: 1)+ \\
\text { turmeric }(0.1: 1)\end{array}$ & 4.44 & 79 & $*$ \\
\hline 9. & Treatment 8 & $\begin{array}{c}\text { F1 + Tiuram } 480 \mathrm{~g} / 1 \\
(5: 5)+\text { clay }(0.5: 1)\end{array}$ & 4.99 & 77 & $* * *$ \\
\hline 10. & Treatment 9 & $\begin{array}{c}\mathrm{F} 2+\text { Tiuram } 480 \mathrm{~g} / \mathrm{l} \\
(5: 5)+\text { clay }(0.5: 1)\end{array}$ & 4.98 & 79 & $* * *$ \\
\hline 11. & Treatment 10 & $\begin{array}{l}\text { F3 + Tiuram } 480 \mathrm{~g} / 1 \\
(5: 5)+\text { clay }(0.5: 1)\end{array}$ & 5.03 & 75 & $* * *$ \\
\hline
\end{tabular}


Table 2. Results obtained after pelleting rape seeds - Test II

\begin{tabular}{|c|c|c|c|c|c|}
\hline \multirow{2}{*}{ Crt. } & \multirow{2}{*}{ Treatment number } & \multirow{2}{*}{ Treatment products } & \multicolumn{3}{|c|}{ Obtained results } \\
\hline & & & MTG (g) & $\begin{array}{c}\text { Germinatie } \\
(\%)\end{array}$ & Semnificatie \\
\hline 1. & Treatment 02 & Control - untreated & 3.32 & 80 & - \\
\hline 2. & Treatment 11 & $\begin{array}{c}\text { F1 + Tiuram } 480 \mathrm{~g} / \mathrm{l}(4: 6)+\text { clay } \\
(0.5: 1)\end{array}$ & 4.96 & 85 & $* * *$ \\
\hline 3. & Treatment 12 & $\begin{array}{c}\text { F2 + Tiuram } 480 \mathrm{~g} / \mathrm{l}(4: 6)+\text { clay } \\
(0.5: 1)\end{array}$ & 5.01 & 85 & $* * *$ \\
\hline 4. & Treatment 13 & $\begin{array}{c}\text { F3 + Tiuram } 480 \mathrm{~g} / \mathrm{l}(4: 6)+\text { clay } \\
(0.5: 1)\end{array}$ & 4.98 & 82 & $* * *$ \\
\hline 5. & Treatment 14 & $\begin{array}{c}\text { F1 + Tiuram } 480 \mathrm{~g} / \mathrm{l}(3.5: 6.5)+\text { clay } \\
(0.5: 1)\end{array}$ & 5.02 & 91 & $* * *$ \\
\hline 6. & Treatment 15 & $\begin{array}{c}\text { F2 + Tiuram } 480 \mathrm{~g} / \mathrm{l}(3.5: 6.5)+\text { clay } \\
(0.5: 1)\end{array}$ & 4.95 & 90 & $* * *$ \\
\hline 7. & Treatment 16 & $\begin{array}{c}\text { F3 + Tiuram } 480 \mathrm{~g} / \mathrm{l}(3.5: 6.5)+\text { clay } \\
(0.5: 1)\end{array}$ & 4.99 & 90 & $* * *$ \\
\hline 8. & Treatment 17 & $\begin{array}{c}\mathrm{F} 1+\text { Tiuram } 480 \mathrm{~g} / \mathrm{l}(3.5: 6.5)+ \\
\text { clay }(1: 1)\end{array}$ & 5.88 & 78 & $* * *$ \\
\hline 9. & Treatment 18 & $\begin{array}{c}\mathrm{F} 2+\text { Tiuram } 480 \mathrm{~g} / \mathrm{l}(3.5: 6.5)+ \\
\text { clay }(1: 1)\end{array}$ & 5.79 & 77 & $* * *$ \\
\hline 10. & Treatment 19 & $\begin{array}{c}\mathrm{F} 3+\text { Tiuram } 480 \mathrm{~g} / \mathrm{l}(3.5: 6.5)+ \\
\text { clay }(1: 1)\end{array}$ & 5.81 & 79 & $* * *$ \\
\hline
\end{tabular}

Another important observation is the one regarding the amount of fungicide used in the treatment mixture (F1 / F2 / F3 + Tiuram $480 \mathrm{~g} / \mathrm{l})$. When 3 1/t seed fungicide, in combination with the bioactive products $(21 / \mathrm{t})$ has been used, the germination results have been quite low, being below the standard limit of $80 \%$, and plantlets growth it has been certainly inhibited, compared to the variants without fungicide (Figure 5) or even those in which fungicide was also used, but in a smaller amount (1.5 and $2 \mathrm{l} / \mathrm{t}$ seed).

The ecological component must also be mentioned, these being considerably diminished by the use of a larger amount of fungicide (TOPA [31]). Basically, the biostimulator is no longer justified in this case. By soaking the seed, it must remain in a micro-environment that ensures its start in vegetation and that provides support on both the nutritional and the protective aspect.
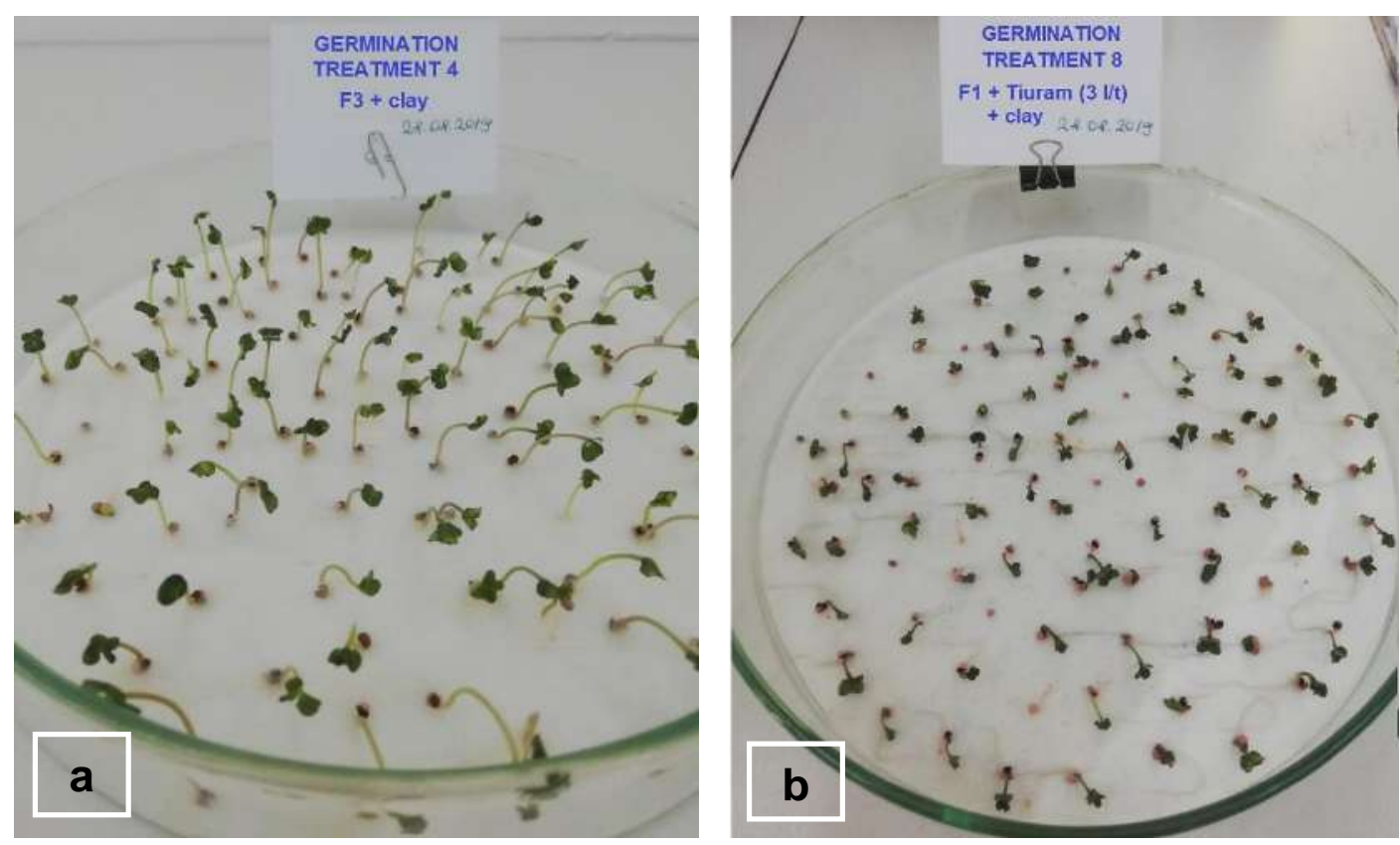

Figure 5. Comparative look between the appearance of rape plantlets as a result of different pelleting Treatment 4 (a) and Treatment 8 (b). 
We also experienced an increase in the number of granulation layers (by doubling the amount of clay to $1: 1$ ), which proved to be unfeasible due to the thickness obtained, which made it difficult for water to access the seed, resulting in low germination and unevenly developed plantlets.

The first measurement of plantlets has been performed 8 days after germination set (Figure 6) for each of the versions selected to be used in the field in autumn (6 pelleted versions and the control one).

Plantlets in each Petri dish have been evaluated as in the photo above, and the data have been entered into an Anova statistical analysis program (Table 3), which calculated all plants average, comparing them with the untreated control.

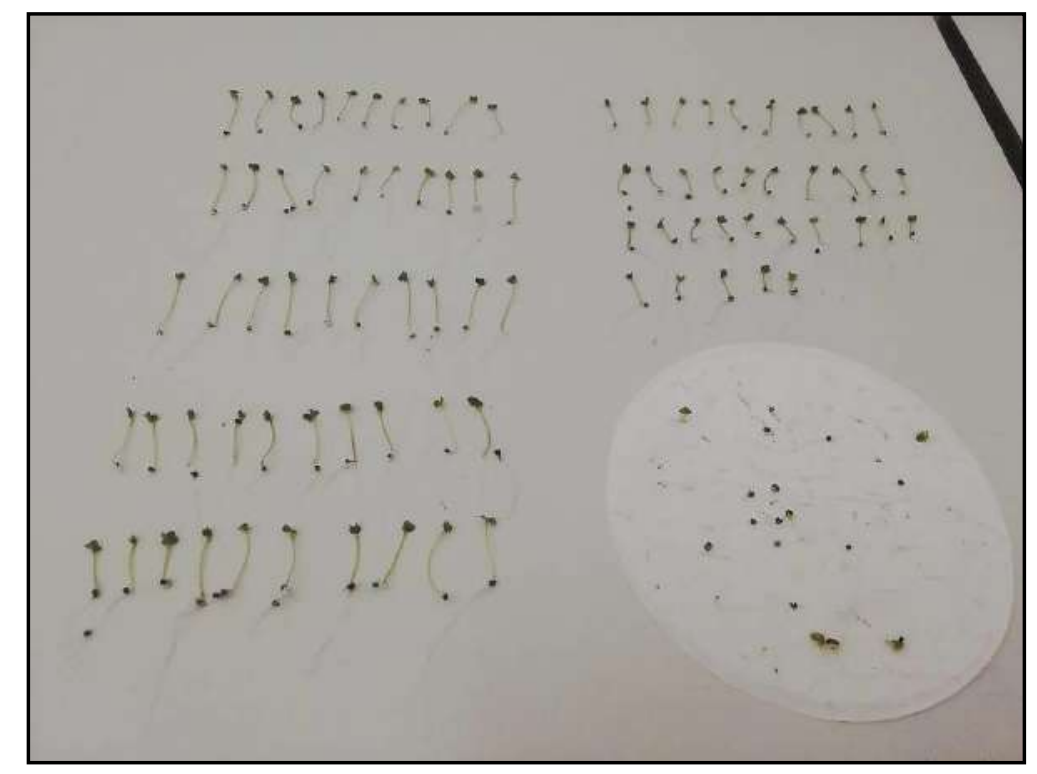

Figure 6. Appearance of rape plantlets after 8 days in the germination chamber.

Table 3. Statistical processing of rape plantlets length at 8 days

\begin{tabular}{|c|c|c|c|c|c|}
\hline \multirow{2}{*}{ Crt. } & \multirow{2}{*}{ Treatment } & \multirow{2}{*}{$\begin{array}{l}\text { Plant length } \\
(\mathrm{cm})\end{array}$} & \multicolumn{2}{|c|}{ Difference } & \multirow[t]{2}{*}{ Semnification } \\
\hline & & & $\mathbf{c m}$ & $\%$ & \\
\hline 1. & Control - untreated & 4.11 & 0,00 & 100.00 & - \\
\hline 2. & $\mathrm{~F} 1+$ clay $(0.5: 1)$ & 4.41 & $+0,30$ & 107.30 & $* *$ \\
\hline 3. & $\mathrm{~F} 2+$ clay $(0.5: 1)$ & 4.29 & $+0,18$ & 104.38 & \\
\hline 4. & F3 + clay $(0.5: 1)$ & 4.18 & $+0,07$ & 101.70 & \\
\hline 5. & $\begin{array}{c}\text { F1 }+ \text { Tiuram }(1.51 / \mathrm{t}) \\
+ \text { clay }(0.5: 1)\end{array}$ & 3.63 & $-0,48$ & 88.32 & o o o \\
\hline 6. & $\begin{aligned} \mathrm{F} 2 & + \text { Tiuram }(1.5 \mathrm{l} / \mathrm{t}) \\
& + \text { clay }(0.5: 1)\end{aligned}$ & 3.34 & $-0,77$ & 81.27 & o 00 \\
\hline 7. & $\begin{aligned} \mathrm{F} 3 & + \text { Tiuram }(1.5 \mathrm{l} / \mathrm{t}) \\
& + \text { clay }(0.5: 1)\end{aligned}$ & 3.06 & $-1,05$ & 74.45 & o o o \\
\hline \multicolumn{2}{|c|}{ Limit differenc } & \multicolumn{2}{|c|}{$\mathrm{LD}_{5 \%}=0.1833$} & 2441 & $\mathrm{D}_{0.1 \%}=0.3179$ \\
\hline
\end{tabular}

In laboratory conditions, the best results have been obtained with the seeds pelleted with the product F1 + clay, in which the length of the plantlets is distinctly significant compared to the control version. The graphic representation in Figure 7 has the role of providing a better visibility of the differences between the tested variants.

\section{Conclusions}

From the pelleting experiments and, later, from the laboratory ones, these measurements emerged as being of great interest, but only if they're going to be completed and compared with the measurement of the plantlets sprouted in the field, which will be the subject of another paper. Although minimal in terms of germination in this first stage, the differences between the pelleted variants are still conclusive from the perspective of the objectives set by the introduction in testing of biostimulatory products of animal origin based on collagen and keratin.

For the future plants, a good start in vegetation ensures an increased resistance to biotic and abiotic factors, which will influence the yields, as well as their quality. An increase of $10-15 \%$ in the number of sprouted plantlets, especially in a year with difficult climatic conditions, can make the difference between a failed crop and an economically viable one. 


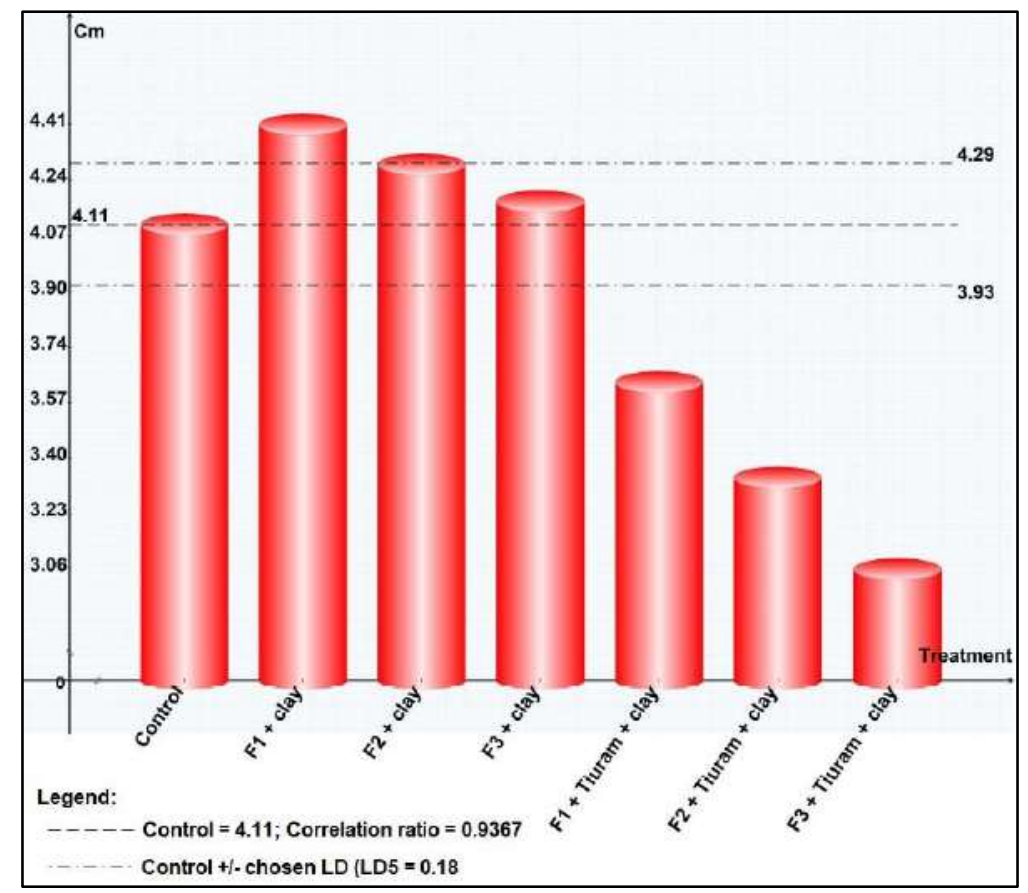

Figure 7. Statistical graph of the length of rape plantlets, at 8 days.

In the laboratory phase of the tests for the new bioactive products, we found that pelleting seeds only with F1 / F2 / F3 and clay, leads to both germination growth, as well as larger and healthier plantlets. On the other hand, the combination of F1 / F2 / F3 and Tiuram fungicide (1.5 1/t) offers good germination, but inhibits the plantlets growth, according to the measurements made after 8 days in the germination chamber. It's possible for these plants to recover along the way, but this aspect can only be verified in the field.

\section{Acknowledgement}

This work was supported by the grant of Romanian National Authority for Scientific Research and Innovation, CCCDI - UEFISCDI, project number: PN-III-P3-3.5EUK-2016-0029 / COLL-RAPE (contract no. 93/2017).

\section{References}

1. J.C. DELOUCHE, H.C. POTTS. The importance of seed in agriculture and the need for a seed program. Paper presented to the Seminar on Improved Rice Seed Production in West Africa, Freetown, Sierra Leone, September 5-9 (1983).

2. FAO. Quality declared seed system. FAO Plant Production and Protection Paper, 185, ISSN: 02592517 (2006).

3. K.K. SHARMA, U.R. SINGH, P. SHARMA, A. KUMAR, L. SHARMA. Seed treatments for sustainable agriculture - A review. Journal of Applied and Natural Science, vol. 7, Issue 1, pp. 521-539, DOI: 10.31018/JANS.V7I1.641 (2015).

4. S.G. ELIAS. The Importance of Using High Quality Seeds in Agriculture Systems. Agricultural Research \&
Technology, vol. 15, Issue 4: 555961, ISSN: 2471-6774 (2018).

5. R. ZECCHINELLI. The influence of seed quality on crop productivity. $2^{\text {nd }}$ World Seed Conference, Rome Italy, September 8-10 (2009).

6. Y. GUAN, J. WANG, Y. TIAN, W. HU, L. ZHU, S. ZHU, J. HU. The Novel Approach to Enhance Seed Security: Dual Anti-Counterfeiting Methods Applied on Tobacco Pelleted Seeds. PLoS ONE, vol. 8, Issue 2, e57274, DOI: 10.1371/journal.pone.0057274 (2013).

7. W.E. FINCH-SAVAGE, G.W. BASSEL. Seed vigour and crop establishement: extending performance beyond adaptation. Journal of Experimental Botany, vol. 67, Issue 3, pp. 567-591, DOI: 10.1093/jxb/erv490 (2015).

8. C.J.M. ALMEKINDERS, K. BEUMER, M. HAUSER, M. MISIKO, M. GATTO, A.O. NKURUMWA, O. ERENSTEIN. Understanding the relations between farmers' seed demand and research methods: The challenge to do better. Outlook on Agriculture, vol. 48, Issue 1, pp. 16-21. DOI: 10.1177/0030727019827028 (2019).

9. A.A. POWELL, S. MATTHEWS. Seed Treatments: Developments and Prospects. Outlook on Agriculture, vol. 17, Issue 3, pp. 97-103 (1988).

10. S.M. IVESON, J.D. LITSTER, K. HAPGOOD, B.J. ENNIS. Nucleation, growth and breakage phenomena in agitated wet granulation processes: a review. Powder Technology, vol. 117, pp. 3-39, DOI: 10.1016/S00325910(01)00313-8 (2001).

11. M.A. BEHJANI, N. RAHMANIAN, N.F.A. GHANI, A. HASSANPOUR. An Investigation on Process of Seeded Granulation in a Continuous Drum Granulation 
Using DEM. Advanced Powder Technology, vol. 28, Issue 10, pp. 2456-2464, DOI: 10.1016/j.apt.2017. 02.011 (2017).

12. L. SUN, Y. XIA, X. ZHAO, Z. GAO, F. YU, J. LU, F. LI, Z. HUA, L. DONG, N. QI. Effects of Seed-pelleting on Physiological Characteristics of Rice. IOP Conference Series: Earth and Environmental Science, vol. 252, 052068, DOI: 10.1088/1755-1315/252/5/ 052068 (2019).

13. J.C. BISHOP. Pelleting Vegetable Seeds - effect on germination and rate of emergence on some seeds. California Agriculture, pp. 6 and 16 (1948).

14. R. KUMAR, R. MUTHUKRISHNAN. Impact of organic seed pelleting on seed germination and seedling development in okra and chilli pepper. International journal of Science and Nature, vol. 6, Issue 3, pp. 480-483, ISSN: 2229-6441 (2015).

15. H.J. HILL. Seed pelleting-history and modern fundamentals. HortScience, vol. 29, Issue 12, pp. 1408, DOI: 10.21273/HORTSCI.29.12.1408d (1994).

16. B. JYOTI, S. BHANDARI. Seed pelleting - A key for enhancing the seed quality. Rashtriya Krishi, Vol. 11, Issue 1, pp. 76-77, ISSN: 2321-7987 (2016).

17. J.A. LEWIS, G.C. PAPAVIZAS, W.J. CONNICK. Preparation of pellets containing fungi and nutrient for control of soilborne plant pathogens. US Patent Number: 4.668 .512 (1987).

18. V.V. GEETHA, P. BALAMURUGAN. Organic Seed Pelleting in Mustard. Research Journal of Seed Science, vol. 4, Issue 3, pp. 174-180, DOI: 10.3923/ rjss.2011.174.180 (2011).

19. M. FAROOQ, A. WAHID, K.H.M. SIDDIQUE. Micronutrient application through seed treatments a review. Journal of Soil Science and Plant Nutrition, vol. 12, Issue 1, pp. 125-142 (2012).

20. D. MIHALACHE, C.A. SÎRBU, A.E. GRIGORE, T.M. CIOROIANU. Protein hydrolysates and aminoacids fertilizers - physicochemical characteristics. Lucrari stiintifice USAMV Iasi, vol. 57, Nr. 2, Seria Agronomie, pp. 47-52 (2014).

21. M.D. NICULESCU, D.G. EPURE, M. LASONRYDEL, C. GAIDAU, M. GIDEA, C. ENASCUTA. Biocomposites based on collagen and keratin with properties for agriculture and industrie applications. The EuroBiotech Journal, vol. 3, Issue 3, pp. 160-166, DOI: 10.2478/ebtj-2019-0019 (2019).

22. M. DOMARADZKI, J. KANIEWSKA, W. WEINER. The Application of agglomerative granulation for seeds. Part 2. Pelleting of organic seeds. Chemic, nr. 5, tom 66, pp. 473-478 (2012).

23. P. GRELLIER, L.M. RIVIERE, P. RENAULT. Transfer and water-retention properties of seedpelleting materials. European Journal of Agronomy, vol. 10, Issue 1, pp. 57-65, DOI: 10.1016/S11610301(98)00050-1 (1999).

24. J. MEI, W. WANG, S. PENG, L. NIE. Seed Pelleting with Calcium Peroxide Improves Crop Establishment of Direct-seeded Rice under Waterlogging Conditions. Scientific Reports, vol. 7, 4878, DOI: 10.1038/s41598017-04966-1 (2017).

25. A. STEPIEN, K. WOJTKOWIAK, R. PIETRZAKFIECKO. Nutrient content, fat yield and fatty acid profile of winter rapeseed (Brassica napus L.) grown under different agricultural production systems. Chilean Journal of Agricultural Research, vol. 77, Issue 3, pp. 266-272, DOI: $10.4067 / \mathrm{S} 0718-58392017000300266$ (2017).

26. J. ZENG, W. SUN, Y. MENG, H. FAN, Y. GAI, J. YE, J. DAI. The effects of sowing date on plant survive rate and seeds yield of winter rapeseed (Brassica rapa) in Northwest China. Proceedings $12^{\text {th }}$ International Rapeseed Congress, Wuhan, China, March 26-30: Sustainable Development in Cruciferous Oilseed Crops, pp. 186-187 (2007).

27. I. BALALIC, A. MARJANIVIC-JEROMELA, J, CRNOBARAC, S. TERZIC, V. RADIC, V. MIKLIC, D. JOVICIC. Variability of oil and protein content in rapeseed cultivars affected by seeding date. Emirates Journal of Food and Agriculture, vol. 19, Issue 6, pp. 404-410. DOI: 10.9755/ejfa.2017-01-229 (2017).

28. S. CHANNAOUI, R. EL KAHKAHI, J. CHARAFI, H. MAZOUZ, M. EL FECHTALI, A. NABLOUSSI. Germination and seedling Growth of a Set of Rapeseed (Brassica napus) Varieties under Drought Stress Conditions. International Journal of Environment, Agriculture and Biotechnology (IJEAB), vol. 2, Issue 1, pp. 487-494, ISSN: 2456-1878, DOI: 10.22161/ijeab/ 2.1.61 (2017).

29. M. GIDEA, C. ENASCUTA, M.D. NICULESCU, D.G. EPURE, E. OPRESCU, C. GAIDAU. Research on the testing of products with biostimulatory effect based on amino acid with potential in the treatment of rape seed. Journal of Biotechnology \& Biomaterials, vol. 8, pp. 33, DOI: 10.4172/2155-952X-C5-100 (2018).

30. K. LAWINSKA, M. LASON-RYDEL, D. GENDASZEWSKA, K. SIECZYNSKA C. GAIDAU, D.G. EPURE, A. OBRANIAK. Coating of Seeds with Collagen Hydrolysates from Leather Waste. Fibres \& Textiles in Eastern Europe, vol. 27, Issue 4, pp. 59-64, DOI: 10.5604/01.3001.0013.1819 (2019).

31. ȚOPA S., MIHĂILESCU S, STRAT D, FLORENTINA GI. Effects of oil pollution on seed germination and seedling emergence toxicity. Rom Biotechnol Lett. 2020; 25(1): 1194-1201. DOI: $10.25083 / \mathrm{rbl} / 25.1 /$ 1194.120 